\title{
Chiron approach for the total synthesis of $(+)$-synargentolide B
}

\author{
Jun Liu ${ }^{\text {a, * }}$, Yangguang Gao ${ }^{b}$, Linlin Wang ${ }^{a}$, Yuguo Du ${ }^{\text {a, b }}$ \\ ${ }^{a}$ State Key Laboratory of Environmental Chemistry and Eco-toxicology, Research Center for Eco-Environmental Sciences, Chinese Academy of Sciences, \\ Beijing, 100085, China \\ b School of Chemistry and Chemical Engineering, University of Chinese Academy of Sciences, Beijing, 100049, China
}

\section{A R T I C L E I N F O}

\section{Article history:}

Received 27 July 2017

Received in revised form

19 September 2017

Accepted 22 September 2017

Available online 22 September 2017

\section{Keywords:}

Chiron approach

Total synthesis

Synargentolide B

\begin{abstract}
A B S T R A C T
A concise and efficient chiron approach for the total synthesis of natural product synargentolide $B$ was achieved in 10 steps with overall yields of 11.3\% from D-mannitol and L-ethyl lactate. The key reactions included anti-Barbier allylation, cross-metathesis, and an intramolecular Yamaguchi esterification.
\end{abstract}

(c) 2017 Elsevier Ltd. All rights reserved.

\section{Introduction}

5,6-Dihydro- $\alpha$-pyrone moiety is an ubiquitous heterocyclic unit found in a number of biologically active natural products, such as synargentolide B (1), ${ }^{1}$ synargentolide A (2), anamarine (3), ${ }^{2}$ synrotolide $(\mathbf{4}){ }^{3}$ which have displayed a variety of biological properties, including cytotoxic, ${ }^{4}$ antifungal and antibacterial activity. ${ }^{5-7}$ (Fig. 1).

Synargentolide A \& B are naturally occurring products consisting of a 5, 6-Dihydro- $\alpha$-pyrone, free or acetylated 1,2-polyols as well as an unsaturated bond and were first isolated from South African genus Syncolostemon argenteus by Rivett et al., in 1998. Initially, the structure of synargentolide B was indecisively established based on extensive spectroscopic analysis. ${ }^{1}$ Almost at the same time, the determination of the absolute stereochemistry of synargentolide B was completed by two groups in $2013 .{ }^{8 a, 8 b}$ Until now, four total syntheses were reported for (+)-synargentolide $B^{8}$ and one synthesis for its analogue ${ }^{9}$ in the literature. Prasad et al. ${ }^{8 a}$ has accomplished the total syntheses of compound $\mathbf{1}$ and its diastereomers starting from (S)-lactic acid and the two enantiomers of tartaric acid using Wittig-Horner reaction and ring-closing metathesis as their key steps. Meanwhile, Sabitha's work ${ }^{8 \mathrm{~b}}$ commenced with D-ribose, D-mannitol, and (+)/(-)-DET to synthesize synargentolide $\mathrm{B}$ and its diastereomers through a tandem

\footnotetext{
* Corresponding author.

E-mail address: junliu@rcees.ac.cn (J. Liu).
}

ring-closing/cross-metathesis reaction.

Herein, we report the synthesis of natural (+)-synargentolide B beginning with $\mathrm{D}$-mannitol and L-ethyl lactate as chiral templates.

\section{Results and discussion}

Our approach for the synthesis of (+)-synargentolide B (1) is depicted in Scheme 1. As shown in Scheme 1, the disconnection process began with two double bonds at $\mathrm{C} 1-\mathrm{C} 2$ and $\mathrm{C} 3^{\prime}-\mathrm{C} 4^{\prime}$, each of which could be realized by a cross-metathesis reaction and an intramolecular Yamaguchi esterification, ${ }^{10}$ respectively. The building block 6 was readily derived from L-ethyl lactate, and the intermediate $\mathbf{7}$ which contains three contiguous chiral centers could be obtained from commercially available D-mannitol.

The synthesis of fragment $\mathbf{6}$ was accessible from L-ethyl lactate over 4 steps as shown in Scheme 2. Protection of L-ethyl lactate as its silyl ether with TBSCl, imidazole in DCM afforded compound 10 in a high yield (96\%). Reduction of compound $\mathbf{1 0}$ by DIBAL-H in $\mathrm{DCM}$ at $-78{ }^{\circ} \mathrm{C}$ furnished the corresponding aldehyde. Subsequent treatment of the aldehyde generated in situ with vinylmagnesium chloride furnished the desired anti product $\mathbf{8}$ as a 5.8:1 mixture of diastereoisomers. ${ }^{11}$ Unfortunately, the attempted separation of the two diastereomers of $\mathbf{8}$ via flash chromatography proved problematic. Deprotection of compound 8 by TBAF in THF followed by peracetylization with acetic anhydride in pyridine provided the building block 6 in 72\% yield as a 7:1 separable mixture of $\mathrm{C}^{\prime}{ }^{\prime}-$ diastereomers.

Reagents and conditions: (a) TBSCl, imidazole, DCM, rt, 96\%; (b) 
<smiles>CC(=O)O[C@@H](/C=C/C(O)C(O)[C@H]1CC=CC(=O)O1)[C@@H](C)OC(C)=O</smiles>

(+)-Synargentolide B (1)<smiles>CC(=O)OC(=O)[C@@H](OC(C)=O)[C@@H](C/C=C/[C@H]1CC=CC(=O)O1)[C@@H](C)OC(C)=O</smiles>

(+)-Synargentolide A (2)<smiles>CC(=O)OC(=O)C(OC(C)=O)C(C=C[C@H]1CC=CC(=O)O1)C(OC(C)=O)[C@@H](C)OC(C)=O</smiles>

Anamarine (3)

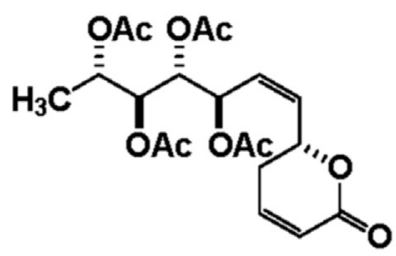

Synrotolide (4)<smiles>CC(=O)OC(C=CC1O[C@@H]1[C@H]1CC=CC(=O)O1)[C@@H](C)OC(C)=O</smiles>

4-deacetoxy-10-epi-olguine (5)

Fig. 1. Chemical structures of natural products containing 5,6-Dihydro- $\alpha$-pyrone.<smiles>CC(=O)O[C@@H](C=CC(O)C(O)[C@H]1CC=CC(=O)O1)[C@@H](C)OC(C)=O</smiles>

(+)-Synargentolide B (1)<smiles>C=CC</smiles><smiles>C=CC(OC(C)=O)[C@@H](C)OC(C)=O</smiles>

6<smiles>C=CC</smiles><smiles>C=CC1OC2OC1C(C)(C)O2</smiles>

7<smiles>C=CC(O)[C@@H](C)O[SbH3]</smiles>

8<smiles>C=CC1OC2OC1C(O)C(/C=C/C(=O)OC)C(C)(C)O2</smiles><smiles>CCOC(=O)C(C)OCC</smiles><smiles>CCC</smiles><smiles>C=CC1OC2OC1C(C)(C=O)O2</smiles>

Scheme 1. Retrosynthetic analysis of (+)-synargentolide B (1).

DIBAL-H, DCM, $-78{ }^{\circ} \mathrm{C}-\mathrm{rt}$, then vinylmagnesium chloride, $\mathrm{Et}_{2} \mathrm{O},-98^{\circ} \mathrm{C}$-rt; (c) TBAF, THF, then $\mathrm{Ac}_{2} \mathrm{O}$, pyridine, $72 \%$ for 4 steps.

As depicted in Scheme 3, our synthesis of compound 7 commenced with D-mannitol, which was converted to 12 in 3 steps in excellent yield according to a modified reported procedure. ${ }^{12}$

Selective hydrolysis of primary acetonide and oxidative cleavage of resulting diol occurred simultaneously with $\mathrm{H}_{5} \mathrm{IO}_{6}$ resulted in $\mathbf{1 1}$ in almost quantitative yield. Allylation of the aldehyde $\mathbf{1 1}$ under the zinc-mediated Barbier reaction gave homoallyl alcohol $\mathbf{1 3}$ as an inseparable anomeric mixture $(81 \%$, anti:syn $=4: 1$, determined by ${ }^{1} \mathrm{H}$ NMR). When aldehyde $\mathbf{1 1}$ was subjected to the Grignard reaction with allylmagnesium bromide in dry ether, homoallyl alcohol $\mathbf{1 3}$ was obtained only in 55\% yield as diastereomeric mixture (65:35).

Reagents and conditions: (d) ref $12,69 \%$ for 3 steps; (e) $\mathrm{H}_{5} \mathrm{IO}_{6}$, $\mathrm{MeOH}, \mathrm{RT}$; (f) Allyl bromide, excess $\mathrm{Zn}$ dust, saturated $\mathrm{NH}_{4} \mathrm{Cl}$, THF, 0-5 ${ }^{\circ} \mathrm{C}, 72 \%$ for 2 steps; (g) methyl acrylate (10 eq), Grubbs' 2nd generation catalyst (0.03eq), DCM, RT, 18 h, 56\%; (h) LiOH, THF, $\mathrm{H}_{2} \mathrm{O}$, RT; (i) 2,4,6-trichlorobenzoyl chloride, pyridine, DCM, $0{ }^{\circ} \mathrm{C}$ to RT, $83 \%$ for 2 steps;

In the next step, we planned to subject diene $\mathbf{1 3}$ to mono-crossmetathesis with methyl methacrylate. To ensure selective monocross-metathesis of diene, the sterically protecting group acetonide is necessary to be present (Scheme 3). In the case of acetonide protected diene 13, best results were obtained with $3 \mathrm{~mol} \%$ of Grubbs' 2nd generation catalyst in DCM at ambient temperature, 5 equiv of methyl acrylate present from the outset, and slow addition of further 5 equiv over $12 \mathrm{~h}$, and the trans- $\alpha, \beta$-unsaturated ester 9 was obtained in $56 \%$ yield with $9 \%$ bis-cross-metathesis byproduct 14. ${ }^{13}$ Treatment of ester 9 with $\mathrm{LiOH}$ in $\mathrm{THF} / \mathrm{H}_{2} \mathrm{O}$ afforded the corresponding acid in almost quantitative yield. ${ }^{10 \mathrm{~b}}$ Intramolecular esterification of acid $\mathbf{1 5}$ under modified Yamaguchi conditions ${ }^{10}$ afforded cis- $\alpha, \beta$-unsaturated lactone 7 in $83 \%$ yield as an $8: 1$ mixture of readily separable diastereomers. The $\delta$-lactonization of 7 could be explained through activation of carboxylic acid with 2,4,6trichlorobenzoyl and subsequent pyridine assisted additionelimination. $^{10 \mathrm{~b}}$

With these two key fragments in hand, we set out to prepare natural (+)-synargentolide B (1) through the planned crossmetathesis (Scheme 4). We are pleased to find that crossmetathesis between side chain $\mathbf{6}$ and core $\mathbf{7}$ was successfully carried out by treatment with Grubbs II catalyst in reflux DCM to provide compound $\mathbf{1 6}$ in 63\% yield with $11 \%$ dimer 17. Finally, removal of the acetonide group in compound 16 by PPTS in $\mathrm{MeOH}$ proceeded smoothly to afford (+)-synargentolide B (1) in 78\% yield. ${ }^{8}$ The physical and spectroscopic data $\left({ }^{1} \mathrm{H}\right.$ and ${ }^{13} \mathrm{C}$ NMR) of our synthetic sample $\mathbf{1}$ were in good agreement with natural product synargentolide $\mathrm{B}^{1}$ 


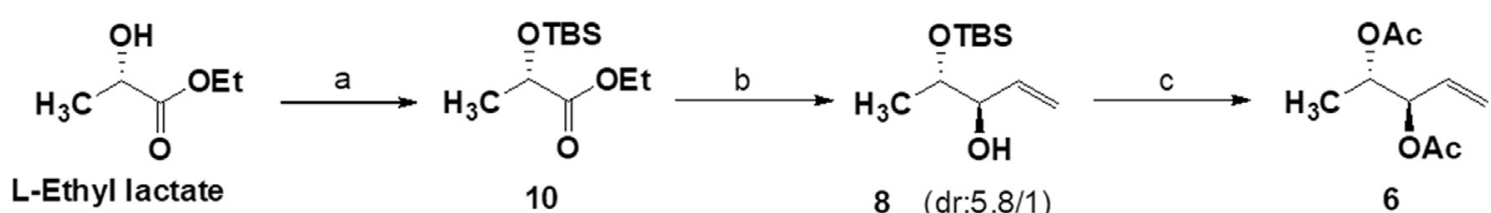

Scheme 2. Synthesis of compound 6.

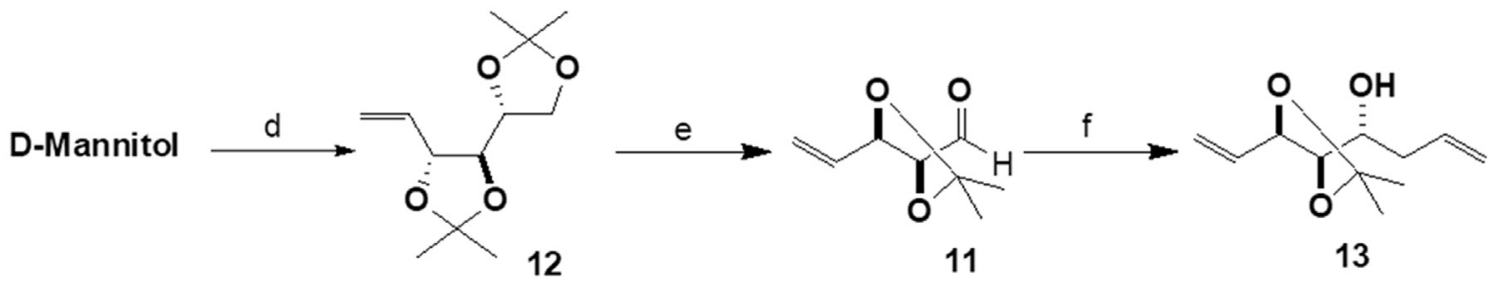

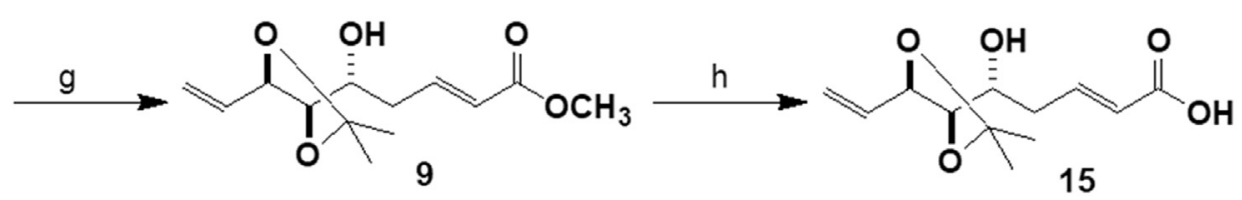

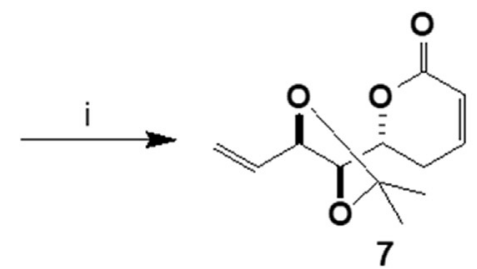<smiles>COC(=O)/C=C/C[C@@H]1OC2(C)CC(/C=C/C(=O)OC)OC1O2</smiles>

14

Scheme 3. Synthesis of compound 7.

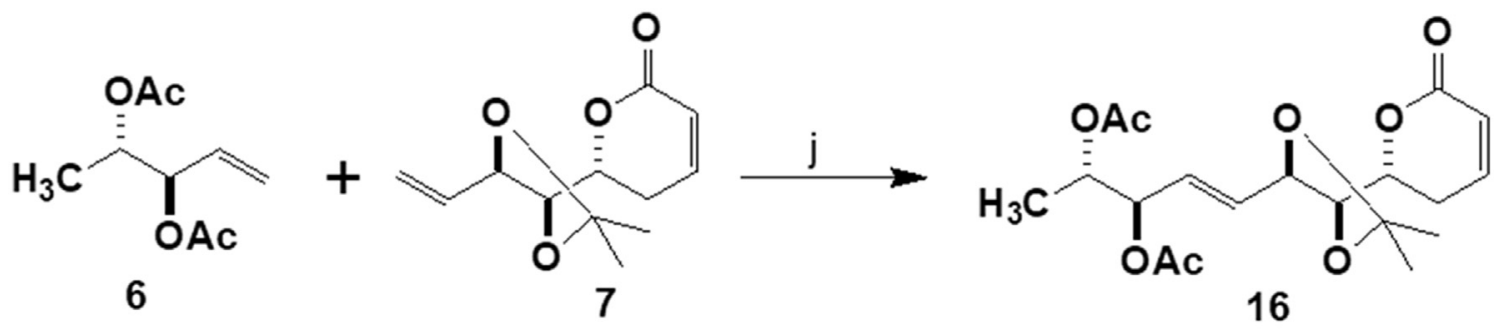

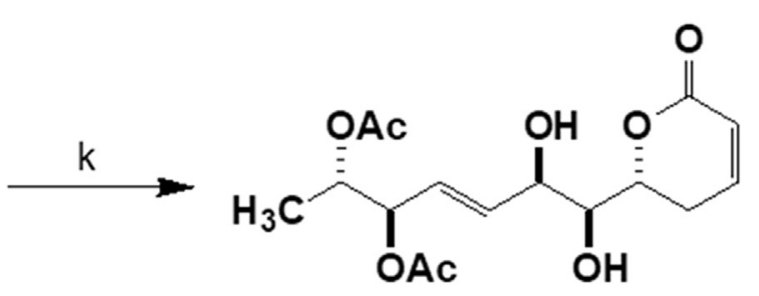

(+)-Synargentolide B (1)

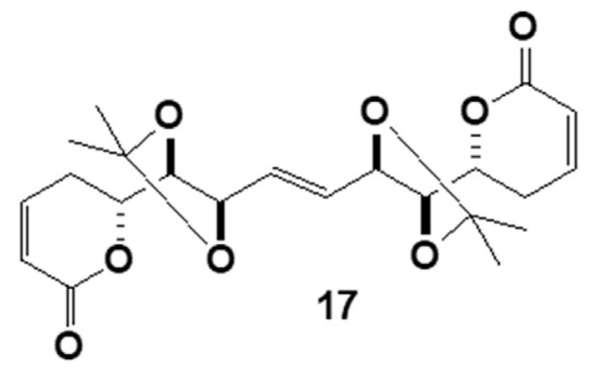




\section{Conclusions}

In summary, natural (+)-synargentolide B was successfully accomplished by using D-mannitol and L-ethyl lactate as chiral template. Key features of our strategy toward practical total synthesis of (+)-synargentolide B are the efficient combination of an anti-Barbier allylation, cross-metathesis, and an intramolecular Yamaguchi esterification. Our convergent and effective strategy provides a candidate for the synthesis of other related synargentolide analogs taking advantage of the inherent chiral centers from natural carbohydrates.

\section{Experimental section}

\subsection{General experimental}

Unless noted otherwise, commercially available materials were used without further purification. Yields refer to chromatographically and spectroscopically ( ${ }^{1} \mathrm{H}$ NMR) homogeneous materials. All solvents were dried according to the established procedures ahead of use. Flash chromatography (FC) was performed using silica gel (200-300 meshes) according to the standard protocol. All reactions under standard conditions were monitored by thin-layer chromatography (TLC) on gel F254 plates. Optical rotations were measured using a polarimeter with a thermally jacketed $5 \mathrm{~cm}$ cell at approximately $25{ }^{\circ} \mathrm{C}$. High-resolution mass spectrometry data (HRMS) were acquired using a Q-TOF analyzer in acetone or methanol as solvent. ${ }^{1} \mathrm{H} \mathrm{NMR},{ }^{13} \mathrm{C}$ NMR were measured on $400 \mathrm{MHz}$ or $100 \mathrm{MHz}$ spectrometers (NMR in $\mathrm{CDCl}_{3}$ with TMS as an internal standard). Chemical shifts $(\delta)$ are given in ppm relative to residual solvent (usually chloroform; $\delta 7.26$ for ${ }^{1} \mathrm{H}$ NMR or 77.0 for proton decoupled ${ }^{13} \mathrm{C}$ NMR), and coupling constants $(J)$ in Hz. Multiplicity is tabulated as $\mathrm{s}$ for singlet, $\mathrm{d}$ for doublet, $\mathrm{t}$ for triplet, $\mathrm{q}$ for quadruplet, and $\mathrm{m}$ for multiplet and $b r$ when the signal in question is broadened.

\subsection{Experimental procedures}

\subsubsection{Synthesis of compound $\mathbf{8}$}

To a solution of TBS protected lactate $\mathbf{1 0}(1.78 \mathrm{~g}, 7.6 \mathrm{mmol})$ in DCM (30 mL) was added DIBAL-H (1.2 M in toluene, $11.4 \mathrm{mmol})$ via syringe at $-98{ }^{\circ} \mathrm{C}$ under $\mathrm{N}_{2}$ protection. After $10 \mathrm{~min}$, vinyl magnesium chloride $(21.5 \mathrm{~mL}, 15 \mathrm{mmol})$ was added into the mixture. The solution was then warmed to room temperature and stirred at room temperature overnight. The reaction was quenched by the addition of saturated $\mathrm{K} / \mathrm{Na}$ tartrate. The aqueous layer was extracted with DCM. The combined organic phase was washed with brine, dried over $\mathrm{Na}_{2} \mathrm{SO}_{4}$ and concentrated under vacuum. The crude allylic alcohol could be used for next step without any purification. A small sample was purified by flash column chromatography (Hexanes/EtOAc 15:1) to get the physical data of $\mathbf{8}$ as a $5.8: 1$ mixture of diastereoisomers: $[\alpha]_{\mathrm{D}}^{25}=+27.6\left(\mathrm{c} 0.45, \mathrm{CHCl}_{3}\right) ;{ }^{1} \mathrm{H}$ NMR $\left(400 \mathrm{MHz}, \mathrm{CDCl}_{3}\right): \delta=5.81$ (ddd, $\left.J=16.8,10.8,6.4 \mathrm{~Hz}, 1 \mathrm{H}\right), 5.28(\mathrm{dt}$, $J=17.2,1.6 \mathrm{~Hz}, 1 \mathrm{H}), 5.20(\mathrm{dd}, J=10.4,1.6 \mathrm{~Hz}, 1 \mathrm{H}), 4.02(\mathrm{q}, J=2.0 \mathrm{~Hz}$, $1 \mathrm{H}), 3.86-3.82(\mathrm{~m}, 1 \mathrm{H}), 2.29(\mathrm{~d}, J=4.0 \mathrm{~Hz}, 1 \mathrm{H}), 1.07$ (d, $J=6.4 \mathrm{~Hz}$, 3H), 0.89 (s, 9H), 0.08 (s, 6H) ppm. ${ }^{13} \mathrm{C} \mathrm{NMR} \mathrm{(100} \mathrm{MHz,} \mathrm{CDCl}_{3}$ ): $\delta=136.6,116.5,71.3,25.8,18.1,17.6,-4.4,-4.9$ ppm; HRMS (ESITOF) $m / z:[\mathrm{M}+\mathrm{Na}]^{+}$Calcd for $\mathrm{C}_{11} \mathrm{H}_{24} \mathrm{O}_{2} \mathrm{SiNa}[\mathrm{M}+\mathrm{Na}]^{+}, 239.1443$; found 239.1461 .

\subsubsection{Synthesis of compound 6}

To a stirred solution of crude $8(0.85 \mathrm{~g}, 0.39 \mathrm{mmol})$ in dry THF $(15 \mathrm{~mL})$ was added TBAF $(1.31 \mathrm{~g}, 5 \mathrm{mmol})$ at room temperature. After completion of the reaction (monitored by TLC), the solution was concentrated under vacuum. The crude diol was used in the next step without further purification. To a vigorously stirred solution of the crude diol in pyridine $(8 \mathrm{~mL})$ was added acetic anhydride $(1 \mathrm{~mL})$. The resulting mixture was stirred at room temperature for $2 \mathrm{~h}$. The reaction was quenched by the addition of $\mathrm{MeOH}(10 \mathrm{~mL})$ and concentrated with toluene. The residue was poured into saturated aqueous $\mathrm{CuSO}_{4}(10 \mathrm{~mL})$ and extracted with DCM $(3 \times 20 \mathrm{~mL})$. The combined organic phase was washed with brine, dried over $\mathrm{Na}_{2} \mathrm{SO}_{4}$ and concentrated under vacuum. The crude was purified by flash column chromatography (Hexanes/ EtOAc 6:1) to give compound 6 as a colorless oil. [ $\alpha]_{\mathrm{D}}^{25}=-37(\mathrm{c} 0.42$, $\left.\mathrm{CHCl}_{3}\right) ;{ }^{1} \mathrm{H}$ NMR $\left(400 \mathrm{MHz}, \mathrm{CDCl}_{3}\right): \delta=5.82-5.71(\mathrm{~m}, 1 \mathrm{H})$, 5.33-5.27 (m, 3H), 5.08-5.01 (m, 1H), $2.07(\mathrm{~s}, 3 \mathrm{H}), 2.02(\mathrm{~s}, 3 \mathrm{H}), 1.18$ $(\mathrm{d}, J=6.4 \mathrm{~Hz}, 3 \mathrm{H}) \mathrm{ppm} .{ }^{13} \mathrm{C} \mathrm{NMR}\left(100 \mathrm{MHz}, \mathrm{CDCl}_{3}\right): \delta=170.4,170.1$, 132.0, 119.4, 75.6, 70.4, 21.1, 21.0, 14.9 ppm; HRMS (ESI-TOF) $m / z$ : $[\mathrm{M}+\mathrm{Na}]^{+}$Calcd for $\mathrm{C}_{9} \mathrm{H}_{14} \mathrm{O}_{4} \mathrm{Na}[\mathrm{M}+\mathrm{Na}]^{+}, 209.0790$; found 209.0773.

\subsubsection{Synthesis of compound 13}

To a solution of the diacetonide $\mathbf{1 2}(150 \mathrm{mg}, 0.66 \mathrm{mmol})$ in EtOAc $(10 \mathrm{~mL})$ was added orthoperiodic acid $(300 \mathrm{mg}, 1.3 \mathrm{mmol})$ at room temperature and stirred for $30 \mathrm{~min}$. The reaction was quenched by aqueous saturated $\mathrm{NaHCO}_{3}(20 \mathrm{~mL})$ and filtered through Celite. The aqueous layer was extracted with EtOAc $(3 \times 20 \mathrm{~mL})$. The combined organic solution was concentrated to give the crude aldehyde $\mathbf{1 1}$ as colorless oil. (Caution: The aldehyde $\mathbf{1 1}$ was highly unstable and decomposed rapidly on flash column or in $\mathrm{CDCl}_{3}$ at room temperature.) The crude aldehyde obtained could be used in the next step without further purification. To a mixture of crude 11 (ca. $0.66 \mathrm{mmol}$ ), $\mathrm{Zn}$ dust ( $86 \mathrm{mg}, 1.32 \mathrm{mmol}$ ) and allyl bromide $(0.114 \mathrm{~mL}, 13.2 \mathrm{mmol})$ in THF $(8 \mathrm{~mL})$ was added a saturated solution of $\mathrm{NH}_{4} \mathrm{Cl}(1 \mathrm{~mL})$ by two portions at $0{ }^{\circ} \mathrm{C}$. After $15 \mathrm{~min}$, the solution was warmed to rt and stirred for further $15 \mathrm{~min}$. The mixture was filtered and washed with brine $(20 \mathrm{~mL})$. The aqueous layer was extracted with EtOAc $(2 \times 20 \mathrm{~mL})$. The combined organic phase was washed with brine, dried over $\mathrm{Na}_{2} \mathrm{SO}_{4}$ and concentrated under vacuum. The crude was purified by flash column chromatography (Hexanes/EtOAc 8:1) to give compound $\mathbf{1 3}$ (95 mg, 72\% over 2 steps) as a mixture of two diastereomers (anti:syn $=4: 1$, determined by crude ${ }^{1} \mathrm{H}$ NMR). $[\alpha]_{\mathrm{D}}^{25}=+97\left(\mathrm{c} 0.6, \mathrm{CHCl}_{3}\right) ;{ }^{1} \mathrm{H}$ NMR (400 MHz, $\left.\mathrm{CDCl}_{3}\right): \delta=5.91-5.76(\mathrm{~m}, 2 \mathrm{H}), 5.42(\mathrm{~d}, J=17.2 \mathrm{~Hz}, 1 \mathrm{H})$, $5.24(\mathrm{~d}, J=10.0 \mathrm{~Hz}, 1 \mathrm{H}), 5.15-5.10(\mathrm{~m}, 2 \mathrm{H}), 4.44(\mathrm{t}, J=7.2 \mathrm{~Hz}, 1 \mathrm{H})$, $3.86-3.83(\mathrm{~m}, 1 \mathrm{H}), 3.73(\mathrm{dd}, J=8.0,4.4 \mathrm{~Hz}, 1 \mathrm{H}), 2.32-2.17(\mathrm{~m}, 3 \mathrm{H})$, $1.42(\mathrm{~s}, 3 \mathrm{H}), 1.40(\mathrm{~s}, 3 \mathrm{H}) \mathrm{ppm} .{ }^{13} \mathrm{C} \mathrm{NMR}\left(100 \mathrm{MHz}, \mathrm{CDCl}_{3}\right)$ : $\delta=136.3134 .0,118.6,118.2,108.9,82.4,78.1,70.3,37.2,26.89$, 26.86 ppm. HRMS (ESI-TOF) $m / z$ : $[\mathrm{M}+\mathrm{Na}]^{+}$Calcd for $\mathrm{C} 11 \mathrm{H} 18 \mathrm{O} 3 \mathrm{Na}$ $[\mathrm{M}+\mathrm{Na}]+221.1153$; found 221.1178.

\subsubsection{Synthesis of compound 9}

Grubbs 2nd catalyst (15 mg, $0.018 \mathrm{mmol}$ ) was added to the mixture of $13(120 \mathrm{mg}, 0.6 \mathrm{mmol})$ and methyl acrylate $(0.271 \mathrm{ml}$, $3.0 \mathrm{mmol})$ in dry DCM $(15 \mathrm{~mL})$. The reaction was stirred at rt and another 5 equiv of methyl acrylate $(0.271 \mathrm{ml}, 3.0 \mathrm{mmol})$ was slow added to the solution over $12 \mathrm{~h}$. After completion of the reaction (monitored by TLC), the solution was concentrated and purified by flash column chromatography (Hexanes/EtOAc 3:1) to give compound 9 as a yellowish oil ( $87 \mathrm{mg}, 56 \%)$. $[\alpha]_{\mathrm{D}}^{25}=+74\left(\right.$ c $\left.2.6, \mathrm{CHCl}_{3}\right)$; ${ }^{1} \mathrm{H}$ NMR (400 MHz, $\left.\mathrm{CDCl}_{3}\right): \delta=7.03-6.91(\mathrm{~m}, 1 \mathrm{H}), 5.94-5.77(\mathrm{~m}$, 2H), 5.43 (d, $J=17.2 \mathrm{~Hz}, 1 \mathrm{H}), 5.27(\mathrm{~d}, J=10.0 \mathrm{~Hz}, 1 \mathrm{H}), 4.43(\mathrm{t}$, $J=7.6 \mathrm{~Hz}, 1 \mathrm{H}), 3.98-3.94(\mathrm{~m}, 1 \mathrm{H}), 3.74-3.64(\mathrm{~m}, 4 \mathrm{H}), 2.45-2.31(\mathrm{~m}$, $2 \mathrm{H}), 2.26$ (br s, $1 \mathrm{H}), 1.43(\mathrm{~s}, 3 \mathrm{H}), 1.41(\mathrm{~s}, 3 \mathrm{H}) \mathrm{ppm} .{ }^{13} \mathrm{C}$ NMR $\left(100 \mathrm{MHz}, \mathrm{CDCl}_{3}\right): \delta=166.6,144.7,136.2,123.7,119.8,109.2,82.4$, 78.2, 70.0, 51.5, 35.7, 27.1, 26.9 ppm. HRMS (ESI-TOF) $m / z:[\mathrm{M}+\mathrm{Na}]^{+}$ Calcd for C13H20O5Na [M + Na]+ 279.1208; found 279.1243. 


\subsubsection{Synthesis of compound 7}

To a solution of $\mathbf{9}(44 \mathrm{mg}, 0.17 \mathrm{mmol})$ in THF $(5 \mathrm{~mL})$ was added $2 \mathrm{M}$ aqueous $\mathrm{LiOH}(3 \mathrm{~mL}$ ) dropwise and the reaction was stirred for $2 \mathrm{~h}$ at room temperature. Amberlite IR-120 $\left(\mathrm{H}^{+}\right)$was then added to neutralize the solution and the mixture was poured into water $(10 \mathrm{~mL})$ and extracted with DCM $(3 \times 10 \mathrm{~mL})$. The combined organic solution was concentrated to give $\mathbf{1 5}$ as colorless oil. The crude acid was used in the next step without further purification. To a solution of crude 15 in pyridine ( $3 \mathrm{~mL}$ ) was added a solution of 2,4,6-trichlorobenzoyl chloride (53 mg, $0.20 \mathrm{mmol})$ in dry DCM $(1 \mathrm{~mL})$ at $0{ }^{\circ} \mathrm{C}$ and the reaction mixture was warmed to room temperature. After completion of the reaction (monitored by TLC), the solution was concentrated under vacuum. The residue was poured into saturated aqueous $\mathrm{CuSO}_{4}(10 \mathrm{~mL})$ and extracted with DCM $(2 \times 10 \mathrm{~mL})$. The combined organic phase was washed with brine, dried over $\mathrm{Na}_{2} \mathrm{SO}_{4}$ and concentrated under vacuum. The crude was purified by flash column chromatography (Hexanes/EtOAc 2:1) to give compound 7 as a colorless oil ( $32 \mathrm{mg}, 83 \%$ for two steps). $[\alpha]_{\mathrm{D}}^{25}=+8.1\left(\mathrm{c} 0.7, \mathrm{CHCl}_{3}\right) ;{ }^{1} \mathrm{H} \mathrm{NMR}\left(400 \mathrm{MHz}, \mathrm{CDCl}_{3}\right): \delta=6.92$ (ddd, $J=8.8,5.2,3.2 \mathrm{~Hz}, 1 \mathrm{H}), 6.03(\mathrm{dt}, J=10.0,0.4 \mathrm{~Hz}, 1 \mathrm{H}$ ), 5.94 (ddd, $J=17.2,10.4,6.4 \mathrm{~Hz}, 1 \mathrm{H}), 5.45(\mathrm{~d}, J=16.8 \mathrm{~Hz}, 1 \mathrm{H}), 5.28(\mathrm{~d}$, $J=10.4 \mathrm{~Hz}, 1 \mathrm{H}), 4.51-4.20(\mathrm{~m}, 2 \mathrm{H}), 3.92(\mathrm{t}, J=7.2 \mathrm{~Hz}, 1 \mathrm{H})$, $2.58-2.53(\mathrm{~m}, 2 \mathrm{H}), 1.45(\mathrm{~s}, 3 \mathrm{H}), 1.43(\mathrm{~s}, 3 \mathrm{H}) \mathrm{ppm} .{ }^{13} \mathrm{C} \mathrm{NMR}$ $\left(100 \mathrm{MHz}, \mathrm{CDCl}_{3}\right): \delta=162.9,144.6,135.3,121.4,118.4,110.0,80.8$, 80.1, 77.8, 27.0, 26.9, 25.9 ppm. HRMS (ESI-TOF) $\mathrm{m} / z$ : $[\mathrm{M}+\mathrm{Na}]^{+}$ Calcd for C12H16O4Na [M + Na]+ 247.0946; found 247.0911.

\subsubsection{Synthesis of compound 16 and 17}

To a stirred solution of lactone $7(72 \mathrm{mg}, 0.32 \mathrm{mmol})$ and diacetate $6(241 \mathrm{mg}, 0.072 \mathrm{mmol})$ in dry $\mathrm{CH}_{2} \mathrm{Cl}_{2}(15 \mathrm{~mL})$ was added Grubbs 2nd catalyst ( $13 \mathrm{mg}, 0.016 \mathrm{mmol}$ ) at room temperature. After being stirred under reflux for $4 \mathrm{~h}$, the brown solution was concentrated and purified by flash column chromatography (Hexanes/EtOAc 2:1) to give compound $\mathbf{1 6}$ as a colorless oil ( $77 \mathrm{mg}, 63 \%$ ) and dimer $17(14 \mathrm{mg}, 11 \%)$. Compound 16: $[\alpha]_{\mathrm{D}}^{25}=+37.8$ (c 1.1, $\left.\mathrm{CHCl}_{3}\right) ;{ }^{1} \mathrm{H} \mathrm{NMR}(400 \mathrm{MHz}): \delta 6.93(\mathrm{dt}, J=9.6,4.0 \mathrm{~Hz}, 1 \mathrm{H}), 6.05(\mathrm{dt}$, $J=9.8,2.0 \mathrm{~Hz}, 1 \mathrm{H}), 5.88-5.60(\mathrm{~m}, 2 \mathrm{H}), 5.42(\mathrm{dd}, J=5.2,4.0 \mathrm{~Hz}, 1 \mathrm{H})$, 5.08 (dq, $J=6.8,3.6 \mathrm{~Hz}, 1 \mathrm{H}), 4.43-4.53(\mathrm{~m}, 2 \mathrm{H}), 3.90(\mathrm{t}, J=7.2 \mathrm{~Hz}$, $1 \mathrm{H}), 2.54-2.57(\mathrm{~m}, 2 \mathrm{H}), 2.10(\mathrm{~s}, 3 \mathrm{H}), 2.06(\mathrm{~s}, 3 \mathrm{H}), 1.45(\mathrm{~s}, 6 \mathrm{H}), 1.23$ $(\mathrm{d}, J=6.8 \mathrm{~Hz}, 3 \mathrm{H}) ;{ }^{13} \mathrm{C}$ NMR $(100 \mathrm{MHz}) \delta 170.4,169.9,162.6,144.6$, 132.4, 127.3, 121.4, 110.4, 80.9, 79.1, 77.9, 74.5, 70.6, 26.9, 26.2, 21.1, 21.0, 15.0; HRMS (ESI-TOF) $m / z$ : $[\mathrm{M}+\mathrm{Na}]^{+}$Calcd for $\mathrm{C} 19 \mathrm{H} 2608 \mathrm{Na}$ : 405.1525, Found 405.1582 .

Compound 17: $[\alpha]_{\mathrm{D}}^{25}-15.8\left(\right.$ c $\left.0.3, \mathrm{CHCl}_{3}\right) ;{ }^{1} \mathrm{H}$ NMR (400 MHz): $\delta 6.90(\mathrm{dt}, J=9.6,4.4 \mathrm{~Hz}, 2 \mathrm{H}), 5.97-6.01(\mathrm{~m}, 4 \mathrm{H}), 4.44-4.50(\mathrm{~m}$, $4 \mathrm{H}), 3.94(\mathrm{t}, J=7.2 \mathrm{~Hz}, 2 \mathrm{H}), 2.54-2.56(\mathrm{~m}, 4 \mathrm{H}), 1.45(\mathrm{~s}, 6 \mathrm{H}), 1.42(\mathrm{~s}$, $6 \mathrm{H}) ;{ }^{13} \mathrm{C}$ NMR (100 MHz) $\delta 162.8,144.7,131.2,121.3,110.1,80.5,79.3$, 77.9, 27.0, 26.9, 26.1; HRMS (ESI-TOF) $m / z$ : $[\mathrm{M}+\mathrm{Na}]^{+}$Calcd for C22H28O8Na: 443.1682, Found: 443.1742.

4.2.7. Synthesis of (+)-synargentolide $B(1)$

To a solution of $\mathbf{1 6}(22 \mathrm{mg}, 0.058 \mathrm{mmol})$ in $\mathrm{MeOH}(5 \mathrm{~mL})$ was added PTSA. $\mathrm{H}_{2} \mathrm{O}$ (4 mg, $0.02 \mathrm{mmol}$ ) at room temperature. The mixture was stirred under reflux for $6 \mathrm{~h}$ and concentrated under vacuum. The crude was purified by flash column chromatography (Hexanes/EtOAc 1:2) to give synargentolide B (1) (15.4 mg, 78\%). $(+)$-Synargentolide $\mathrm{B}:[\alpha]_{\mathrm{D}}^{25}=+39\left(c 0.45, \mathrm{CHCl}_{3}\right) ;[\alpha]_{\mathrm{D}}^{24}+25.8(c 1.2$, $\mathrm{MeOH}) ;[\alpha]_{\mathrm{D}}^{24}+23.3(\text { c } 1.2, \mathrm{MeOH})^{8 \mathrm{a}} ;{ }^{1} \mathrm{H}$ NMR $\left(400 \mathrm{MHz}, \mathrm{CDCl}_{3}\right)$ : $\delta=6.95$ (ddd, $J=9.2,4.8,3.6 \mathrm{~Hz}, 1 \mathrm{H}), 6.04(\mathrm{~d}, J=9.2 \mathrm{~Hz}, 1 \mathrm{H}), 5.89$ $(\mathrm{dd}, J=15.6,4.8 \mathrm{~Hz}, 1 \mathrm{H}), 5.81(\mathrm{dd}, J=15.6,6.0 \mathrm{~Hz}, 1 \mathrm{H}), 5.31-5.34$ $(\mathrm{m}, 1 \mathrm{H}), 5.06(\mathrm{dq}, J=6.8,3.6,1 \mathrm{H}), 4.48-4.54(\mathrm{~m}, 2 \mathrm{H}), 3.71-3.73(\mathrm{~m}$, 1H), 2.75 (br s, 2H), 2.55-2.57 (m, 2H), 2.09 (s, 3H), 2.05 (s, 3H), 1.21 $(\mathrm{d}, J=6.4 \mathrm{~Hz}, 3 \mathrm{H}) ;{ }^{13} \mathrm{C}$ NMR $\left(100 \mathrm{MHz}, \mathrm{CDCl}_{3}\right): \delta=170.5,170.2$, 163.5, 145.6, 134.1, 127.0, 121.0, 76.8, 75.0, 74.4, 70.6, 69.5, 25.7, 21.3, 21.2, 15.2 ppm. HRMS (ESI): calcd. for $\mathrm{C}_{16} \mathrm{H}_{22} \mathrm{O}_{8} \mathrm{Na}[\mathrm{M}+\mathrm{Na}]^{+}$, 365.1212 ; found 365.1248 .

\section{Acknowledgments}

This work was supported by the National Basic Research Program of China (Grant 2015CB931903), the National Key Research and Development Program of China (2016YFA0203102), the Strategic Priority Research Program of Chinese Academy of Sciences (Grant XDB14040201) and NNSF of China (Projects 21372254 and 21321004). We thank Dr. Wei Liu and Qi Yu for HRMS measurements.

\section{Appendix A. Supplementary data}

Supplementary data related to this article can be found at https://doi.org/10.1016/j.tet.2017.09.041.

\section{References}

1. Collett LA, Davies-Coleman MT, Rivett DEA. Phytochemistry. 1998;48:651-656. 2. Alemany A, Márquez C, Pascual C, et al. Tetrahedron Lett. 1979;20:3583-3586.

3. Coleman MTD, English RB, Rivett DEA. Phytochemistry. 1987;26:1497-1499.

4. Hoffmann HMR, Rabe J. Angew Chem Int Ed. 1985;24:94-110.

5. (a) Larsen AK, Escargueil AE, Skladanowski A. Pharmacol. Ther. 2003;99: 167-181;

(b) Richetti A, Cavallaro A, Ainis T, Fimiani V. Immunol. Pharmacol. Immunotoxicol. 2003;25:441-449.

6. Pereda-Miranda R, Garcia M, Delgado G. Phytochemistry. 1990:29:2971-2974.

7. Delgado G, Pereda-Miranda R, Romo DA. Heterocycles. 1985;23:1869-1872.

8. (a) Prasad KR, Gutala P. J Org Chem. 2013;78:3313-3322;

(b) Sabitha G, Shankaraiah K, Yadav JS. Eur J Org Chem. 2013:4870-4878.

(c) Konda S, Bhaskar K, Nagarapu L, Akkewar DM. Tetrahedron Lett. 2014;55: 3087-3089;

(d) Ramulu U, Rajaram S, Ramesh D, Babu KS. Tetrahedron Asymmetry. 2015;26: 928-934.

9. Kumaraswamy G, Raghu N, Jayaprakash N, Ankamma K. Tetrahedron. 2015;71: 5472-5477

10. (a) Ono M, Zhao XY, Shida Y, Akita H. Tetrahedron. 2007;63:10140-10148; (b) Cai C, Liu J, Du YG, Linhardt RJ. J Org Chem. 2010;75:5754-5756.

11. Liu J, Liu Y, Zhang X, et al. J Org Chem. 2012;77:9718-9723.

12. (a) Yadav VK, Agrawal D. Chem Comm. 2007:5232-5234; (b) Yadav IS, Das S, Mishra AK. Tetrahedron Asymmetry, 2010:21:2443-2447.

13. (a) Scholl M, Ding S, Lee CW, Grubbs RH. Org Lett. 1999;1:953-956; (b) Chatterjee AK, Choi TL, Sanders DP, Grubbs RH. J Am Chem Soc. 2003;125: $11360-11370$. 